\title{
Many hamsters: how the EU can enable private firms to provide renewable energy
}

\section{John Simister*, Dimitrios Syrrakos, Fred Day and Richard Whittle}

\author{
Business School, \\ Manchester Metropolitan University, \\ Oxford Road, Manchester M15 6BH, UK \\ Email: j.g.simister@mmu.ac.uk \\ Email: d.syrrakos@mmu.ac.uk \\ Email: f.day@mmu.ac.uk \\ Email: R.Whittle@mmu.ac.uk
}

\begin{abstract}
This paper investigates the energy investment needs of the European Union (EU), including renewable energy. Europe currently has little or no economic growth, and interest rates are expected to rise. Given the state of many EU countries' economies, this is a good time to encourage investment because - according to Keynesian economics - extra spending can stimulate economic activity. The current economic situation limits options for many governments in EU countries, so new approaches may be required. This paper uses ideas from the European Commission, on how a 'smart' electricity grid can enable renewable energy - such as solar power. The EU Parliament could enable a market-provided solution by offering incentives to the private sector. Private investment will be encouraged if the EU gives long-term low-interestrate loans for renewable energy generation. Also, a Europe-wide grid makes it profitable to locate solar panels in low-wage countries in southern Europe, and sell electricity in richer countries.
\end{abstract}

Keywords: renewable energy; solar power; wind power; smart grid; European Union; European commission; economic recovery.

Reference to this paper should be made as follows: Simister, J., Syrrakos, D., Day, F. and Whittle, R. (2014) 'Many hamsters: how the EU can enable private firms to provide renewable energy', Int. J. Green Economics, Vol. 8, No. 2, pp.158-176.

Biographical notes: John Simister is a Senior Lecturer in the 'Accounting, Finance \& Economics' department of Manchester Metropolitan University. He teaches various areas of Undergraduate Economics. He has taught at UK universities including LSE, SOAS and King's College London. He has published dozens of articles in peer-reviewed academic journals, and appeared on $\mathrm{BBC}$ television and radio.

Dimitrios Syrrakos is a Senior Lecturer in the 'Accounting, Finance \& Economics' department of Manchester Metropolitan University. He has taught various areas of Undergraduate Economics, including macroeconomics and monetary union in the European Union. He has published in peer-reviewed academic journals. He is regularly interviewed on BBC television. 
Fred Day is a Senior Lecturer in the 'Accounting, Finance \& Economics' department of Manchester Metropolitan University. He has worked in the UK commercial banking sector, and has taught various areas of Undergraduate Economics. He has presented conference papers in several countries, and is the leader of the 'Pluralist Political Economy' research cluster at MMU.

Richard Whittle is a Senior Lecturer in the 'Accounting, Finance \& Economics' department of Manchester Metropolitan University. He has taught undergraduate and Postgraduate Economics, and has taught for organisations such as the Bank of New York. He has been successful in bids for academic funding, and created masters' degree programmes at MMU. He has published in peer-reviewed journals, and is on the board of an academic journal.

\section{Introduction}

The current economic environment in the European Union remains fragile. The Eurozone economy is about to enter its third recession since 2009 and further its strategy based on fiscal consolidation is failing to deliver. Draconian fiscal cuts implemented in the Eurozone countries have led to the collapse of domestic demand gradually, but steadily, leading to an erosion in Eurozone demand, hitting hard (in particular in the last two years) the French and Italian economies. The gradual realisation of the impasse these policies has led to gives rise to the search of new policies that could potentially be utilised as a means of providing a long-term solution. The policies employed in the USA seem to offer an obvious alternative. Notwithstanding the differences featuring the USA and the Eurozone or the European Union economies, the policies pursued so far in the USA have had a much more positive impact on the recovery of the US economy since 2009. They present therefore a paradigm worthy of consideration by the EU authorities.

One of the unintended consequences of the EU economic policies since 2009 is risk reduction when investing in EU countries' bond markets. While this has been relatively successful, it has led to an increased risk of private sector losses, in particular when investing in EU countries' bond markets. As a result, the current economic environment limits private sector investment. This includes investment in renewable energy, a sector vital for the sustainability of all EU economies.

Indeed, European consumption fell since 2008; Europe currently has little private investment (Koo, 2013, p.143). Observ'ER (2012, pp.115-121) reports that Italian solar power is at a standstill; German solar power subsidies have been cut; no immediate increase in solar capacity expected in France; UK solar panels subsidies halved in 2011; and Spanish government support for renewable energy removed in 2012. "The situation in Europe is fraught. Many medium-sized companies are going into voluntary liquidation, closing subsidiaries or plants to cut their losses" (Observ'ER, 2012, p.121). Renewable energy in the EU is stalled (Observ'ER, 2012, pp.115-121; European Commission, 2010, p.3; Pew Charitable Trusts, 2012, p.52): “The ongoing debt crisis in Europe is likely to make it difficult to sustain the region's clean energy investments in coming years" (Pew Charitable Trusts, 2012, p.52). "Europe's leading role in the PV market is coming to an end [...] Going forward, the driving forces will be in countries like China, the USA, Japan and India" (EPIA, 2013a, p.6). 
The fiscal squeeze of Portugal, Ireland and Greece in 2011-2012 has caused contagion to Spain and Italy in 2012 and 2013, as reflected by the increased interest rate, premium financial markets require when investing in these countries' bond markets. It has also led to an increased interest rate for debt servicing, to a lesser extent in France and Belgium, reflecting the EU dimension of the problem. As a result, specific Eurozone countries' fiscal and financial difficulties encountered, in particular when trying to recycle national debt, has led to an EU-wide problem with consequences not anticipated when the first bail out was provided in Greece in spring 2010.

However, the PIIGS are endowed with solar resources to a greater extent than the northern Eurozone countries. These resources, coupled with appropriate policies at an EU level, can provide the way forward for these countries by restoring their fiscal sustainability and financial credibility. However, the 'appropriate' policies at an EU level based on raising funds for investment in solar power are subject to a revision of the current economic orthodoxy, championed by the fiscally prudent countries in the Eurozone, namely Germany, Austria, Finland and the Netherlands, accompanied by Denmark and Sweden at an EU-wide framework. In the absence of these policies, investing in solar power is rendered impossible, subjecting PIIGS to a chronic process of fiscal consolidation with no impeding end, and above all, with no guarantee that the policies will deliver.

A process is already set in motion by the economic developments and policies implemented in France that, although not diametrically opposing the policy prescriptions 'suggested' by Germany, certainly present a challenge to them and put them to the test of delaying deficit reduction by two years, against the will of the European Commission. These developments could potentially stall current policies in EU countries, which generally impose austerity. The slowdown in German economic growth would be the decisive factor, in terms of determining the speed for such a revision.

The solution put forward in this paper therefore focuses on bringing together Keynesian economic policies at an EU and Eurozone level, based on fiscal expansion and in particular increases in government expenditure and renewable energy, in especially solar. Although it is recognised that there are many other areas requiring urgent financial assistance such as education and healthcare, investing in the energy sector provides several long-term benefits. Firstly, it is conducive to limiting global warming; second, it reduces dependence on imported energy; and, thirdly, it plugs the gap resulting from the decommissioning of nuclear energy. Investing in electricity seems unlikely to crowd out (discourage) investment in other sectors. Lastly, it can boost long-term investment and employment creation in EU countries and regions that have experienced unprecedented high unemployment rates.

The rest of the paper is organised as follows. In section 2, a Keynesian view of recessions is provided, with an emphasis placed on the 2007-2009 financial and economic crisis and its implications for economic policies. In section 3, the differences between the nature of government and private sector incentives are identified. Proposals for bringing together the two types of incentives in the energy sector are also presented and discussed. In section 4, energy from renewable sources is considered, by primarily focusing on the case of solar power. Finally, in section 5, the main conclusions are presented. 


\section{A Keynesian analysis of recessions}

The global financial crisis has dominated Europe since the Lehman Brothers bank collapsed (Schäfer, 2012, p.181); Worth (2010) called it the 'second Great Depression'. An economy in a mild recession may repair itself, but Keynes (1936, p.324) suggested it could take 25 years to achieve optimal employment and investment. Japan shows that an economic slump can last for decades. The European economy or at least the Eurozone economies seem to be following Japan's demise from its economic apogee in the midlate 1980s. Six years from the onset of the Eurozone debt crisis in 2009, the grim economic outlook of the area, including Germany, makes the prospect of a 'lost decade' a realistic outcome with immense consequences for employment, let alone the evolution of EU institutions.

Kitromilides (2011, p.526) claimed, "If the markets form the view that the 'age of austerity' strategy is counterproductive, this may further strain, rather than calm down market nerves, and change perceptions of what constitutes a 'credible' government policy to deal with ballooning deficits." Koo $(2013$, p.145) claimed in the current recession, "government borrowing and spending becomes absolutely indispensable in saving the economy". IMF (2012) estimated that "in the years, additional global financing of potentially $\$ 1$ trillion could be needed [...] countries like Italy and Spain, that are fundamentally able to repay their debts, and could potentially be forced into a solvency crisis by abnormal funding costs". Delong et al. (2012, p.235) wrote: "Financial crises and demand-induced recessions appear to have an impact on potential output even after normal conditions are restored. This makes it plausible that measures that mitigate their effects would have long-run benefits."

If consumer spending and investment are too low, Keynesians recommend more government spending, to create jobs; this could include public works, like the US government's 'New Deal' in the 1930s. The effect of recessions could be softened if governments "boost the public-spending component of environmental policies" (Kennet et al., 2013, p.318). Government debt-financed expenditure may be appropriate in a recession (Todorova, 2013, p.70); fiscal policy is more effective than monetary policy in a recession (Koo, 2013; Blanchard and Leigh, 2013). Kitromilides (2011, p.523) and Blanchard and Leigh (2013) suggested that government spending helps an economy recover from recession. Delong et al. (2012, p.235) wrote that "at moments like the present - when interest rates are constrained by the zero bound, the output gap is large, and cyclical unemployment is high - fiscal policy is likely to be more potent than standard estimates suggest. This conclusion boosts the benefits of expansionary fiscal policy in a depressed economy substantially".

In response to the 2008 global crisis, "At year-end 2008, about $\$ 6.8$ trillion in new federal government loans, liability guarantees or asset guarantees to financial services firms was outstanding that had not existed a year earlier" (FDIC, 2009, p.17); renewable energy was part of the stimulus package (European Commission, 2010, p.8). Since 2008, "the Obama administration allocated more than ninety billion dollars (of nearly eight hundred billion dollars total) in grants and tax incentives for a host of clean energy programs" (Simmons et al., 2014, p.38). EU governments spent much less: $\$ 3.2$ billion in 2010 and \$2.6 billion in 2011 (Pew Charitable Trusts, 2012, p.31). Since 2008, President Obama's Keynesian policies (e.g. supporting the US car industry) seem successful, because USA experienced about 2\% growth per year from 2009 (OECD, 2014b). Other countries such as Germany enacted similar stimulus packages, and "many countries' 
economies started to recover quickly after the enactment of stimulus packages" (Dullien, 2012, p.8). However, some European countries (such as Greece, Italy, Ireland, Portugal and Spain) had to reduce government spending (Dullien, 2012, p.10): austerity was forced on Eurozone countries after 2008, because of balance-of-payments deficits; rising national debts (due to nationalisation of troubled financial institutions); and fear of financial markets (Kitromilides, 2011, p.520). If a Eurozone country defaults on its debts, it could initiate a chain of events leading to the end of the Euro (Strobel, 2005) - causing chaos. Many economists have argued that reform of financial institutions in Europe is needed (Syrrakos, 2010). Issing (2000) argued that the Euro requires political union. The European Financial Stability Facility and the European Stability Mechanism may help, but are not sufficient for the current crisis: the existence of the Euro currency and even the EU are threatened (Syrrakos, 2010). Capital flight occurred from peripheral Eurozone countries to Germany, lowering German interest rates (Koo, 2013, p.147). Some European governments were downgraded by rating agencies such as standard and poor (Bastasin, 2012, pp.94-95), raising their cost of borrowing. Many observers, such as Griffith-Jones and Jolly (2013, p.46), argue Europe must change course and follow President Obama's lead: "François Hollande, the new President, has suggested a new program for European growth, which in principle has been accepted by European leaders at the summit in late June 2012. The program adopted by the leaders would represent an increase in investment of as much as 1 percent of GDP in the European Union (EU). It is key that it be implemented quickly and on a sufficient scale so as to have sufficient impact soon on growth and employment."

The European Commission (2010) argues for intervention by the European Parliament, to facilitate recovery from the economic crisis, and to tackle the problems facing the energy sector. "The urgent task for the EU is to agree the tools which will make the necessary shift possible and thus ensure that Europe can emerge from recession on a more competitive, secure and sustainable path" (European Commission, 2010, p.3). Griffith-Jones and Jolly (2013, p.50) wrote: "Coordinated by the international organisations in the 2008 crisis, governments have acted as a banker of last resort - but not as an employer of last resort for protecting workers and stimulating employment. In this respect, the treatment of labour was totally different from the treatment of finance and capital. The banks gained, but the people suffered. More seriously, the lack of broader action means that the crisis still continues".

\section{Government vs. private investment?}

In order for European governments to become the 'employer of last resort' in terms of enhancing the regions' growth potential and promote policies conducive to job creation, a change in the way they view the fiscal injection for investment projects should take place. While 'old-fashioned' above-inflation wage increases in public sector employees should be ruled out as an option, raising funds for investment programmes may be the only viable solution to the current impasse. The energy sector provides an excellent framework for such investment projects.

Indeed, since 2010 the European Commission (2010) has had a plan to address energy problems and to help Europe survive the economic crises, estimating the cost by 2020 to have been as much as $€ 1$ trillion. This amount seems arbitrary, but the European Commission is the only agency which can write EU legislation. Data comparing US with 
EU expenditure are indicative of this. The US federal government deficit was $10 \%$ of GDP in $2009,9 \%$ in 2010 and $8.7 \%$ in 2011 - a total injection of about $28 \%$ of GDP (Obama, 2012, Table 15.6), i.e. the USA invested 28\% more than Europe did. The US fiscal injection far exceeds the European Commission (2010) recommendation of $€ 1$ trillion, which is $8.3 \%$ of EU GDP in 2013 (Eurostat, 2012a; Eurostat, 2012b).

Pew Charitable Trusts (2012, pp.39-43) reported public and private spending on solar power in 2011 as $\$ 4.4$ billion in France, \$19.9 billion in Germany, and \$28 billion in Italy. Solar power generating capacity in these countries in 2011 increased by 2.7, 7.4, and 10.2 GW, respectively; 'Feed-in' tariff systems varied between EU countries (Observ'ER, 2012, pp.115-121). These figures imply that the cost of solar power (in \$ billion per GW) was 1.63 in France, 2.69 in Germany and 2.75 in Italy - a weighted average of approximately $€ 1.85$ billion (using exchange rate $€ 0.79$ per US\$: OECD, 2012). Hence, $€ 1$ trillion should pay for $540 \mathrm{GW}$ of solar power peak generating capacity (output is lower when skies are cloudy, and at night: Grossmann et al., 2012, p.168). Solar electricity generating capacity in EU was $51 \mathrm{GW}$ in 2011 (Observ'ER, 2012, p.114), so an additional $540 \mathrm{GW}$ would increase solar power to about $15 \%$ of EU electricity needs. This would create jobs (one firm had 3690 employees per GW of solar electricity production capacity Grossmann et al., 2012, p.177).

Renewable energy has 'public good' aspects: benefits are non-excludable (every EU citizen would gain from cleaner air, reduced risk of global warming, and less dependence on imported fuel). The EU could pay for solar panels directly; but many economists advocate production by private firms.

Cherrier (2013) investigated economics as engineering, including "engagement with policy making", to nudge private firms towards socially desirable outcomes. Minsky (1992, p.5) wrote "increasing complexity of the financial structure, in connection with a greater involvement of governments as refinancing agents for financial institutions as well as ordinary business firms (both of which are marked characteristics of the modern world), may make the system behave differently than in earlier eras. In particular, the much greater participation of national governments in assuring that finance does not degenerate as in the 1929-1933 period means that the down side vulnerability of aggregate profit flows has been much diminished". Griffith-Jones and Jolly (2013, pp.46-47) suggested a balanced-budget multiplier could help Europe: increase tax and government spending by similar amounts, in richer countries such as Germany.

Electricity from solar energy is no more expensive than generating electricity from fossil fuels in parts of Italy and Spain (Grossmann et al., 2012, p.167), so investing in solar power could be profitable. The price of electricity generated by solar panels fell in recent decades, but is still not quite competitive with other forms of electricity generation such as gas (Borenstein, 2012, p.86; Grossmann et al., 2012, p.167). Observ'ER (2012, p.131) predicted solar power will reach 'grid parity' by 2016 for the residential sector; but for investment to occur before 2016, subsidies may be needed, such as feed-in tariffs for rooftop solar panels on houses (Pew Charitable Trusts, 2012, p.6). The cost of maintaining solar power facilities is below US\$ 10 per MW hour (Grossmann et al., 2012, p.168).

Renewable energy systems often require very large initial investments (such as installing solar panels or a wind farm, and connecting cables to the electricity distribution network), followed by decades of profits from selling electricity - there is a long payback period. Market interest rates are currently low, but it would be risky to borrow for such long-term investments using commercial loans. EU policy is "a failure due to the lack of 
long-term price signals to induce large investments in low-carbon technologies" (Edenhofer et al., 2013, p.S14). "Without European cooperation, public funds will not be able to channel investment into technologies of the future which are still too risky for investors. [...] A genuine common European energy policy is the only solution" (European Union, 2012, p.14). Since the 2008 global crisis, Bastasin (2012, p.62) wrote of "The timidity of the European Commission in the wake of real emergencies". "Renewed political resolve is needed to restore investor confidence, remove bottlenecks and maintain a reliable but dynamic framework for the remuneration of PV" (EPIA, 2013a, p.57; emphasis in original).

The European Investment Bank (2013) announced a $€ 0.65$ billion 'Climate Awareness Bond'; the European Central Bank could arrange for much larger loans. Griffith-Jones and Jolly (2013) and European Commission and EIB (2013) suggest compromise between state and private investment is desirable. European Commission and EIB (2013, pp.11-12) discussed three ways to lend to Small and Medium Enterprises (SME), based on $€ 10.4$ billion of public funds from 'Competitiveness of Enterprises and Small and Medium-sized Enterprises' (COSME) and Horizon 2020, and European Structural and Investment Funds (ESIF) with EIB \& 'European Investment Fund' (EIF) resources:

- Option 1 is for new loans, blending $75 \%$ of guarantees with $25 \%$ of securitisation. Portfolios would be built up by banks in 2-3 years, generating about $€ 55$ billion of lending: a leverage ratio of 5 .

- Option 2 allows securitisation of new and existing SME loan portfolios. This would increase the impact, allowing lending about $€ 65$ billion: a leverage of roughly 6 .

- Option 3 is like option 2, but adds existing SME loans and working capital. Pooling risks allows for a better portfolio diversification, so this option generates lending of $€ 100$ billion: a leverage of about 10 .

Griffith-Jones and Jolly (2013, pp.46-47) have put similar suggestions forward, suggesting Keynesian intervention using one or more of three 'paths':

- First 'path': raise the EU budget by $€ 5$ billion, which the EIB could use as a risk buffer, lending an extra $€ 10$ billion via 'project bonds'. EIB money (using a mezzanine or intermediate tranche) forms $25 \%$ of total investment, with $25 \%$ by private investors, and $50 \%$ by insurance companies and pension funds. $€ 40$ billion of new investment flows from a $€ 5$ billion injection: a leverage ratio of 8 .

- Second 'path': increase EIB capital by some EU member states injecting loans. Participating EU country governments pay $5 \%$ of desired total spending. For an initial $€ 11.6$ billion public investment, the EIB lends $€ 95$ billion initially, and $€ 105$ billion in the following three years. The EIB often co-finances with the private sector, so this $€ 200$ billion could increase by a further $€ 190$ billion.

- Third 'path': add existing European Structural Funds which have been agreed, but not yet been used. This could add $€ 25$ billion per year from 2014 .

Combining these three 'paths', according to Griffith-Jones and Jolly, would have injected $0.5 \%$ of EU GDP from 2013 to 2015 . One of these options, or one of the 'paths' suggested by Griffith-Jones and Jolly (2013), could fund renewable energy - but cost taxpayers less than the $€ 1$ trillion needed to modernise EU energy, according to European 
Commission (2010). Griffith-Jones and Jolly (2013, pp.48-49) claim rating agencies will maintain EIB's AAA status if leverage does not exceed 8. To increase financial injections to $€ 1$ trillion, (richer) EU governments need to invest more than Griffith-Jones and Jolly (2013) and European Commission and EIB (2013) suggest. Political decisionmaking is complicated, probably requiring agreement between the EU parliament and national governments of EU countries such as Germany and France. However, the recent turbulence in financial markets and the resurgence of Europe's debt problems may prompt the EU member countries' leaders to review their approach and attitude to renewable energy investment programmes.

Renewable power can be intermittent and also is associated with 'common-mode failure' (Boisvert, 2012). The solution may be an EU-wide electricity grid. "Utilities don't like to make way for intermittent renewable surges by turning off coal, nuclear, and combined-cycle gas plants; firing up the boilers after a shut-down takes time and wastes fuel and money, and they will need those generators back on line, quickly, when wind and solar cut out" (Boisvert, 2012). Private firms are unlikely to build a Europe-wide electricity grid; but the EU could do this by combining with cheap loans to the firms producing renewable energy.

The European Parliament could impose a centrally planned system of electricity generation. It is difficult for a central planner to dictate power generation at each location: a small miscalculation might be costly to European taxpayers, distorting electricity generation. Many economists advocate free-market solutions to such problems: competition between firms provides good outcomes for consumers, as each firm has a strong incentive to find out if (for example) 'concentrated solar power' is more cost-effective than photovoltaic power in a particular location. But due to market failures, any "decentralized market solution generated by decentralized agents like firms, consumers and investors that do not take into account relevant multiple externalities of their actions, e.g. climate damages, technological spill-overs, and security standards, cannot be expected to yield the welfare-optimal quantity" of renewable energy (Edenhofer et al., 2013, p.S13). If neither central planning nor free markets produce a good outcome, what might work?

"Scientific and economic experts are in increasing agreement that our current energy paradigm is no longer tenable, not least due to reserve and supply uncertainties, price volatility, and fiscal and environmental strains on the world's major markets and ecosystems" (Simmons et al., 2014, p.29). We next turn to energy from renewable sources.

\section{Energy from renewable sources}

Gnansounou (2011, p.399) and European Commission (2010) expressed concern about dependence on imported energy. Europe imports most of its energy (European Union, 2012, p.5); EU is the world's largest importer of energy, and "Our standard of living requires huge amounts of energy" (European Union, 2012, p.3). Decommissioning older European electricity plants has reduced output from nuclear power, coal and fuel oil (EPIA, 2013a, p.42). Fossil fuels such as oil or gas may become less reliable and more expensive as accessible sources become exhausted. Potential for nuclear power seems limited: uranium stocks for nuclear fission may run out in the next few decades (European Commission, 2007, p.26); nuclear fusion seems decades from commercial 
production. European Commission (2010, p.3) warned that some parts of the EU could lose more than a third of their existing generation capacity by 2020, as nuclear power plants are decommissioned. Shale gas (via 'fracking') might reduce water availability for farming; contaminate water supplies, soil and air; exacerbate global warming; and cause earthquakes - "the lack of public acceptance represents a barrier to further shale gas development" (European Commission, 2014, pp.5-7).

Photovoltaic solar panels now provide about $2.6 \%$ of Europe's electricity (EPIA, 2013a, p.6). Renewable energy has advantages, including less dependence on imported fuels; lower pollution, such as greenhouse gas emission; and in the long term, lower electricity prices (fossil fuel prices are expected to rise as reserves decline, whereas renewable energy is becoming cheaper) (Observ'ER, 2011). European Commission (2007, p.3) wrote:

\footnotetext{
"Energy accounts for $80 \%$ of all greenhouse gas (GHG) emission in the EU; it is at the root of climate change and most air pollution. The EU is committed to addressing this - by reducing EU and worldwide greenhouse gas emissions at a global level to a level that would limit the global temperature increase to $2^{\circ} \mathrm{C}$ compared to pre-industrial levels. However, current energy and transport policies would mean $\mathrm{EU} \mathrm{CO}_{2}$ emissions would increase by around $5 \%$ by 2030 and global emissions would rise by $55 \%$. The present energy policies within the EU are not sustainable."
}

Wind and solar power "have lower nameplate prices than nuclear" electricity (Boisvert, 2012). Renewable energy could support many objectives - including energy security, reduced environmental damage, green jobs, green growth and poverty reduction (Edenhofer et al., 2013, p.S13). Solar power research is being carried out in Europe, including Spain (Fernández-Reche et al., 2006), Finland (Hashmi et al., 2011) and Germany (Prucnal et al., 2012). EU support for solar power could encourage technological advances, keeping Europe at the forefront of non-polluting energygenerating technology (creating long-term jobs and exporting renewable energy equipment to the rest of the world). Grossmann et al. (2012, p.186) predicted global employment in the production of solar panels will increase to 2 million people by 2030 .

EU support for renewable energy could provide internal and external economies of scale, and also promote more research - improving efficiency from new technologies such as 'Passivated Emitter and Rear Cell' or 'Passivated Emitter and Rear LocallyDiffused' panels (Observ'ER, 2012, p.125). "Europeans consider that the European Union is best placed to take effective action against the effects of the financial and economic crisis"; in 2012, 58\% of respondents support "increasing the share of renewable energy in the EU by $20 \%$ by 2020" (European Commission, 2012, p.20; p.22). $73 \%$ of Europeans interviewed consider it important "to support an economy that uses fewer natural resources and emits less greenhouse gas" (European Commission, 2012, p.21). Food production may increase due to partial shade from solar panels, because some crops are damaged by 'photoinhibition', i.e. too much sunlight (Murchie et al., 2009, p.541).

In 2007, the European Commission advocated every EU country "should have the flexibility to promote the renewable energies most suited to their specific potential and priorities" (European Commission, 2007, p.14). But the European Commission (2010, p.20) had a new viewpoint: "Secure energy supplies, an efficient use of resources, affordable prices and innovative solutions are crucial to our long-term sustainable growth, job creation and quality of life. Member States have agreed that these challenges 
will be tackled most effectively by policies and action at EU level, by 'Europeanising' energy policy. This includes directing EU funding support towards public priorities that markets fail to meet and that bring the most European value".

\subsection{Calculation}

To provide a geographical perspective on this plan to help Europe, we now report statistical evidence in the form of graphs and maps. This paper cites ten countries as case studies. The 'PIIGS' (Portugal, Ireland, Italy, Greece and Spain) are often used as examples of troubled EU countries; the other five (the Netherlands, Belgium, Denmark, Germany and Finland) experienced much better economic growth since 2008. Figure 1 shows the national income per person at constant prices (OECD, 2014a: series LNBQR): Gross Domestic Product (GDP) using the expenditure approach, in national currency. The authors divide GDP by population (series POPNC) and then convert this to an index, equal to 100 in 2008 quarter 1. Equivalent Greek data are unavailable, so Greece data in Figure 1 are from OECD (2014a: series VOBARSA: in national currency). The authors smooth the data, using a 'moving average' process.

Figure 1 GDP since 2008, in ten case study countries

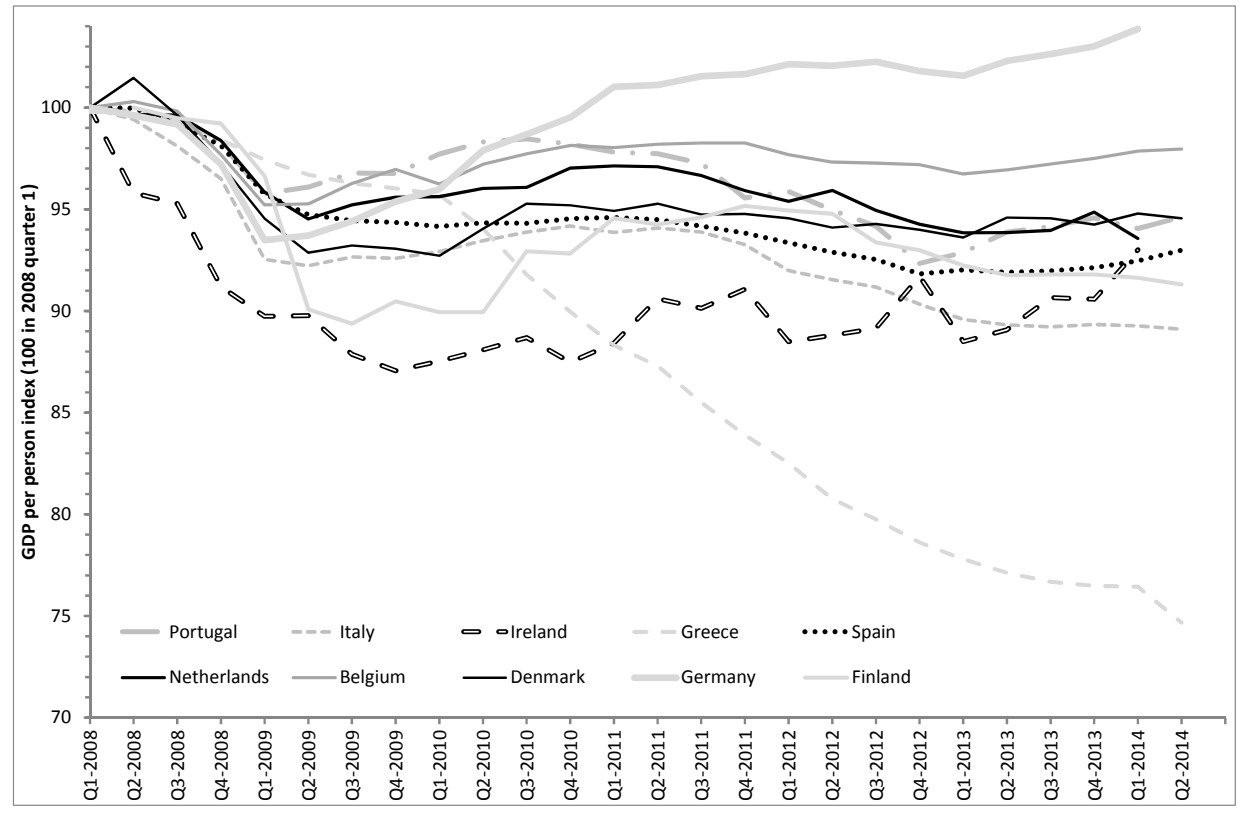

Source: OECD (2014a): index calculated by authors

Figure 2 was produced by the authors, using software on the Eurostat (2014b) website; Figure 2 uses youth unemployment as a proxy for poverty in general. Countries are indicated using NUTS1 boundaries; NUTS2 regions are also shown. 
Figure 2 Unemployment rate among young adults (age 15-24) in 2012

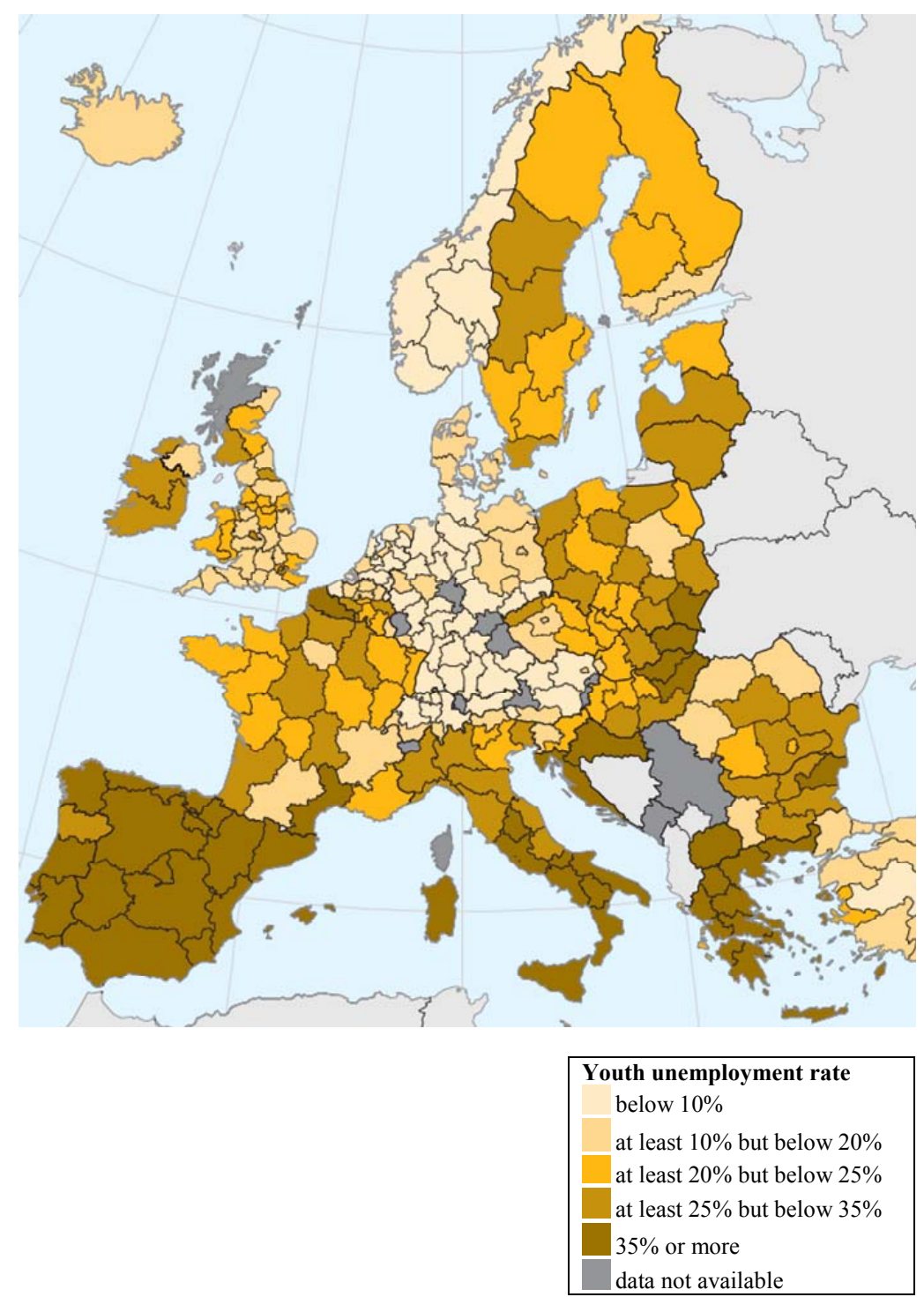

Source: Authors' analysis using Eurostat (2014b)

\subsection{Results}

The evidence presented in this section allows us to assess links between geographical, economic and political factors in Europe, in particular the question of whether policy decisions should be taken at national level or by the European Union.

Figure 1 depicts Germany and (to a lesser extent) Finland recovering since 2008; other countries show little or no recovery. All European countries could benefit from 
more investment, to reduce unemployment and raise living standards; but Figure 1 makes it clear that some countries are more in need than others. To put Figure 1 in context, Figure 2 represents youth unemployment - as a measure of poverty in Europe.

Of the ten case study countries investigated in this paper, the most serious economic problems appear to be in southern Europe - as shown in Figure 1. Figure 2 confirms this picture: areas with the highest youth unemployment tend to be in southern Europe. Perhaps by coincidence, problem areas in southern Europe seem to match areas of greatest solar power potential: as noted in section 2, above, southern Europe is the most appropriate location for solar power (for an EU-wide system). Figure 3 indicates which parts of Europe have the most sunlight, using 'Global Horizontal Irradiation' from SolarGIS (2014); southern Europe is appropriate for solar power: Portugal, Italy, Greece and Spain are particularly effective locations.

Figure 3 Solar irradiation in Europe

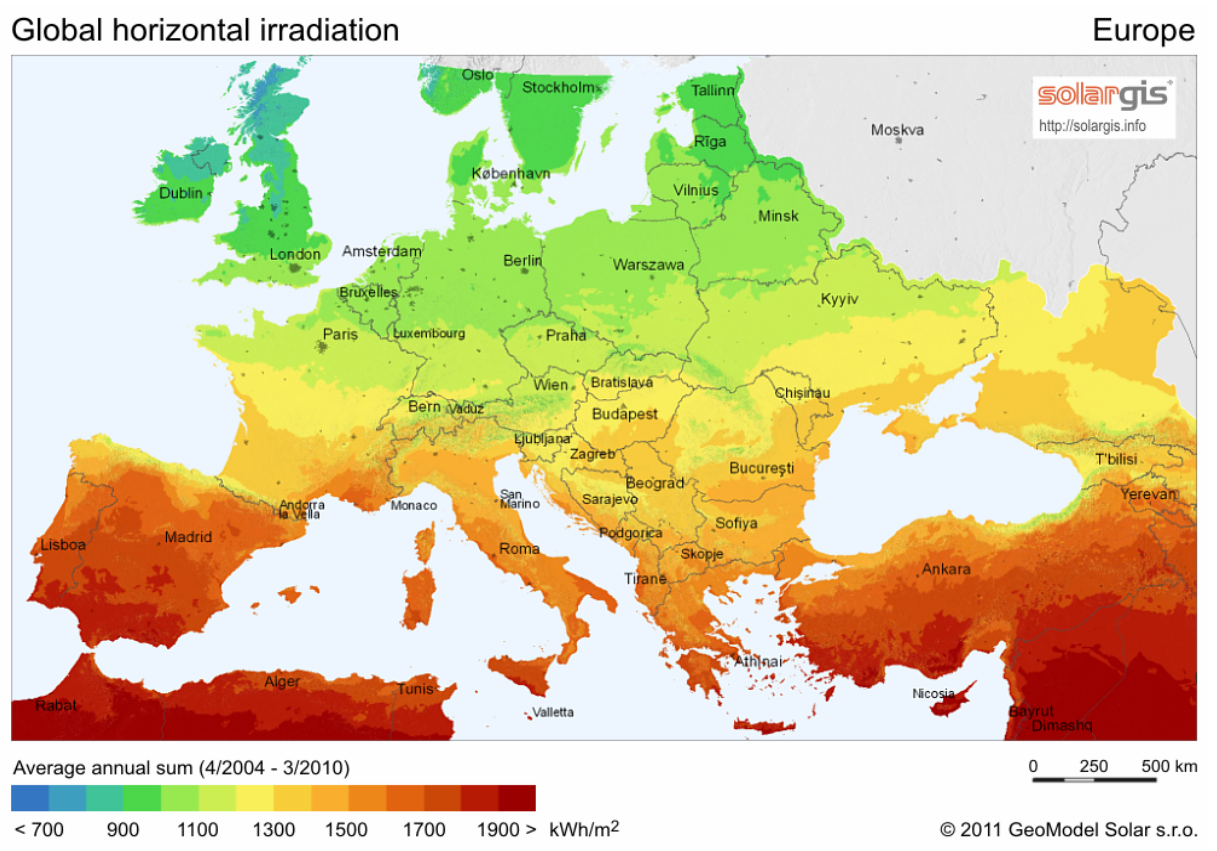

Source: SolarGIS (2014)

Borenstein (2012, p.72) claimed, "The three broad categories of renewable energy that are considered closest to being scalable and cost competitive are wind, solar, and biomass". Of these, "Solar power is produced only during daylight hours and tends to peak in the middle of the day. In many areas, this is close to coincident with the highest electricity demand, which usually occurs on summer afternoons" (Borenstein, 2012, p.74), whereas wind power often produces most power at times of lower demand and prices. This suggests that most EU funding should go towards solar power; the most appropriate location for solar power is southern Europe, e.g. Spain, Portugal, Italy and Greece (Strobel et al., 2009; Nielsen et al., 2010), which (according to Figures 1 and 2) are currently in urgent need of support. Wind power could be also supported, especially in northern Europe. 
Southern Europe seems ideal to produce solar power - but local electricity prices may be low; areas of high electricity demand are often in northern Europe. This suggests a north-south dimension is needed, in a European electricity grid. Also, wind and solar power output is influenced by the weather (Edenhofer et al. 2013, p.S17). A grid could smooth solar power supply variation due to local clouds (EPIA, 2012, pp.25-28), and also smooth demand variations over time by combining consumption in east and west Europe:

\begin{abstract}
"It's a bit like having a bunch of hamsters generating your power, each in a separate cage with a treadmill. At any given time, some hamsters will be sleeping or eating and some will be running on their treadmill. If you have only one hamster, the treadmill is either turning or it isn't, so the power's either on or off. With two hamsters, the odds are better that one will be on a treadmill at any given point in time and your chances of running, say, your blender, go up. Get enough hamsters together and the odds are pretty good that at least a few will always be on the treadmill, cranking out the kilowatts." (American Meteorological Society, 2007)
\end{abstract}

Hence, the European Parliament may need to pay for a 'smart grid' to distribute electricity. Brancucci Martínez-Anido et al. (2013, pp.207-208) wrote, "the European transmission network is experiencing serious underinvestment". European Commission (2013b) claimed over 40\% more capacity in Europe's electricity transmission will be needed by 2020 . The electricity distribution grid must be 'smart' "to avoid the need for costly interventions in the future" (EPIA, 2012, p.9). Because energy from sunshine and wind vary with the weather, more reliance on renewable energy "highlights the need to accelerate the modernisation of the electricity grid" including grid balancing and improved flexibility; electricity should be generated "where it makes most economic and environmental sense. Factors such as distance to consumption centres, implied grid needs and issues related to public acceptance and job creation clearly also play a role and cannot be ignored" (European Commission, 2011, p.5). EPIA (2013b) claimed, "The Renewable Energy Directive requires Member States to upgrade their electricity infrastructure in time to allow for the large-scale integration of renewable power. The European Commission should systematically control the effective implementation of this requirement. As decentralised generation will have to become a key component of the energy system, a stronger focus on the distribution grid system will be required to allow for the cost-effective integration of renewable energy sources such as solar PV." Eurostat (2014a) data confirm that in 2013, electricity prices differed dramatically between countries, suggesting an EU-wide grid could benefit consumers in high-price countries and producers in low-price countries (for example, it would help Germany cope without nuclear power).

Investing in solar power could be effective in helping Europe out of recession. But can southern European governments afford to support such investments? To assess this, Figure 4 uses 'financial net worth' of each country's government as a proportion of that country's GDP. Large government debts make it difficult for state agencies in PIIGS countries to borrow - even if the Troika had not imposed spending rules on them. At the time of writing, some European governments seem powerless: due to previous borrowing (bailing out commercial banks), governments cannot borrow at interest rates low enough to support private investment. 
Figure 4 Debt levels since 2008, in ten case study countries

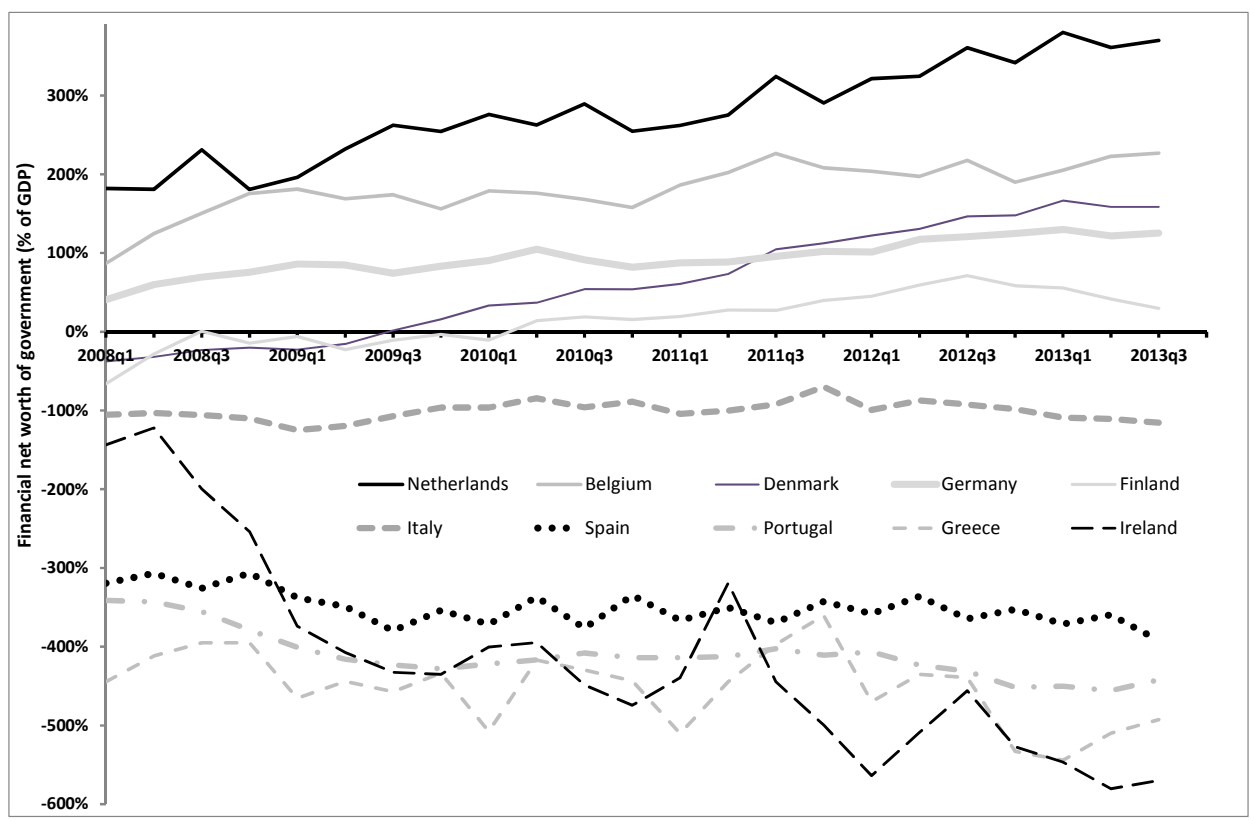

Source: OECD (2014b)

Figure 4 indicates a problem: the five PIIGS countries, which are in most need of fiscal injection, are least able to afford it. Figure 4 shows high levels of government debts in these five countries. But debts in many European countries are not at alarming levels, compared with historical standards: for example, UK national debt in 2013 (quarter 3) was $89 \%$ of GDP (OECD, 2014b), compared with 200\% after the Second World War (although average debt maturity complicates this issue). Hence, it may be plausible for countries such as Germany to borrow money, in order to support investment in southern Europe. However, such deals are difficult to coordinate; international electricity distribution requires a coordinated approach - which might be arranged by the European Union.

If countries most affected by crisis (e.g. Greece) are prioritised for investments by the European Union, modelling using the HEIMDAL algorithm suggests this would raise EU GDP by about $0.6 \%$ and create 1.2 million jobs in two years; indirect effects such as improved business confidence would help further (Griffith-Jones and Jolly, 2013, pp.48-49).

\section{Discussion}

Edenhofer et al. (2013, p.S18) claimed, "An urgent question in this context is how to bring and integrate [renewable energy] technologies into the market." Evidence in this paper suggests an EU-wide approach can solve the current energy and economic crises facing Europe. Some EU countries, such as Germany, can borrow cheaply; other EU countries, such as Greece and Spain, desperately need investment. Some EU countries 
(such as Germany) will decommission existing power plants; other EU countries (such as Greece and Spain) are excellent places to locate electricity-generating facilities based on solar power. In normal times, capitalist firms could use these factors as an opportunity to make profits; but in the current climate, risks of rising interest rates and low electricity prices in southern Europe make such investments a distant prospect - unless the EU steps up to the mark.

Could Europe invest $€ 1$ trillion to modernise its energy infrastructure? Socialist and Green MEPs might support renewable energy investment, but a majority may require a private sector approach. Private firms will not invest unless profitability is assured. Keynesians claim that Europe needs fiscal injections to generate recovery, but MEPs are unlikely to support such policies. Many politicians are against state intervention. Compromise might be possible, but would be Byzantine: for example, should MEPs persuade voters by emphasising global warming or high unemployment?

Conventional Keynesian demand management relies on government spending. An alternative, suggested in this paper is a compromise between government and private sector spending: such a compromise might secure support in the European Parliament. If the European Commission (2010) estimate that $€ 1$ trillion investment is needed in Europe's energy is correct, then EU institutions could use leverage to partly finance $€ 1$ trillion on renewable energy (Griffith-Jones and Jolly, 2013; European Commission and EIB, 2013). If a leverage ratio of 10 were used, this might be achieved by a loan of $€ 100$ billion from richer EU countries, or alternatively be provided by the European Investment Bank, which can borrow at low interest rates (Koo, 2013). Such a one-off loan would be cheaper than the EU Common Agricultural Policy, which cost taxpayers $€ 58$ billion in 2011 (European Commission, 2013a) - an ongoing cost.

Keynes (1936, p.383) wrote, "the ideas of economists and political philosophers [...] are more powerful than is commonly understood. Indeed the world is ruled by little else". European Commission President Jean-Claude Juncker might arrange legislation to achieve a majority in the European Parliament, to move Europe from Japanese-style recession to USA-style growth. While compromise will be difficult to reach, it is not unattainable. If the current economic climate is to endure, it may be the only solution in the years to come.

The European Commission has developed plans to develop a Europe-wide system to generate and distribute electricity: an EU-wide 'smart grid'. Renewable energy investment could achieve many goals, including resolving financial problems of European countries; lowering unemployment; ensuring sustainable energy supplies; and reducing pollution such as greenhouse gases, to combat global warming. Free-market solutions have made progress in replacing some of Europe's electricity generation - but the pace is too slow to meet expected challenges, such as Germany's decommissioning of nuclear power stations. Central planning does not seem feasible for electricity generation on the scale advocated by the European Commission: and other innovative thinking is required. To achieve the aims outlined by the European Commission (2010), this paper suggests the EU enable private sector investments, with support from low-interest-rate loans from EU agencies such as the European Central Bank.

The EU economies are experiencing a short-term problem, of recession (lowering incomes and increasing unemployment). The EU also faces a long-term problem, with energy (reliance on imported energy and burning fossil fuels). This paper offers a pathway to solve both problems, based on EU support for renewable energy. The solution has two key elements: long-term loans to private firms for renewable energy generation 
and a 'smart grid', which allows a firm to generate electricity in a location with plenty of sunshine (in south Europe), and sell the electricity to consumers in rich (north Europe) countries. It requires an agreement between the EU parliament and national political leaders. The resulting proactive policy mix, which would combine Keynesian policies with private sector incentives, could allow the entire EU to achieve sustainable economic growth conducive to fiscal sustainability.

\section{References}

American Meteorological Society (2007) The power of multiples: connecting wind farms can make a more reliable - and cheaper - power source. Available online at: www.eurekalert.org/ pub_releases/2007-11/ams-tpo112107.php (accessed on 22 September 2014).

Bastasin, C. (2012) Saving Europe: How National Politics Nearly Destroyed the Euro, Brookings Institution, Washington, DC.

Blanchard, O. and Leigh, D. (2013) Forecast Errors and Fiscal Multipliers, IMF Working Paper. Available online at: www.imf.org/external/pubs/ft/wp/2013/wp1301.pdf (accessed on 15 March 2013).

Boisvert, W. (2012) 'Green energy bust in Germany', Dissent. Available online at: www.dissentmagazine.org/article/green-energy-bust-in-germany (accessed on 23 September 2014).

Borenstein, S. (2012) 'The private and public economies of renewable electricity generation', Journal of Economic Perspectives, Vol. 26, No. 1, pp.67-92.

Brancucci Martínez-Anido, C., Vandenbergh, M., de Vries, L., Alecu, C., Purvins, A., Fulli, G. and Huld, T. (2013) 'Medium-term demand for European cross-border electricity transmission capacity', Energy Policy, Vol. 62, No. 10, pp.207-222. Available online at: http://dx.doi.org/ 10.1016/j.enpol.2013.05.073.

Cherrier, B. (2013) The rise of economics as engineering I: setting the scene, Institute for New Economic Thinking. Available online at: ineteconomics.org/blog/playground/rise-economicsengineering-ii-case-study (accessed on 21 November 2013).

Delong, J.B., Summers, L.H., Feldstein, M. and Ramey, V.A. (2012) 'Fiscal policy in a depressed economy [with comments and discussion]', Brookings Papers on Economic Activity, Vol. 44, pp.233-297.

Dullien, S. (2012) 'Is new always better than old? On the treatment of fiscal policy in Keynesian models', Review of Keynesian Economics, Vol. 1, pp.5-23.

Edenhofer, O., Hirtha, L., Knopf, B., Pahle, M., Schlömer, S., Schmid, E. and Ueckerdt, F. (2013) 'On the economics of renewable energy sources', Energy Economics, Vol. 40, pp.S12-S23.

EPIA (2012) Connecting the Sun: Solar Photovoltaics on the Road to Large-Scale Grid Integration', European Photovoltaic Industry Association, Brussels, Belgium. Available online at: www.epia.org/fileadmin/user_upload/Publications/Connecting_the_Sun_Full_ Report_converted.pdf (accessed on 8 September 2014).

EPIA (2013a) Global Market Outlook for Photovoltaics 2013-2017, European Photovoltaic Industry Association, Brussels, Belgium. Available online at: www.epia.org/fileadmin/user_ upload/Publications/GMO_2013___Final_PDF.pdf (accessed on 8 September 2014).

EPIA (2013b) EPIA Responses to the European Commission Green Paper: 'A 2030 framework for climate and Energy Policies', European Photovoltaic Industry Association, Brussels. Available online at: www.epia.org/news/position-papers/ (accessed on 9 September 2014).

European Investment Bank (2013) EIB launches largest EUR climate awareness bond (CAB) ever, press release, 12 July. Available online at: www.eib.org/investor_relations/press/2013/2013109-eib-launches-largest-eur-climate-awareness-bond-cab-ever.htm (accessed on 18 July 2013). 
European Commission (2007) An Energy Policy for Europe, SEC(2007)12, European Commission, Brussels.

European Commission (2010) Energy 2020: A Strategy for Competitive, Sustainable and Secure Energy, SEC(2010)1346, European Commission, Brussels. Available online at: http://register.consilium.europa.eu/doc/srv?l=EN\&f=ST\%2016096\%202010\%20INIT (accessed on 20 October 2014).

European Commission (2011) Renewable Energy: Progressing Towards the 2020 Target, SEC(2011)131, European Commission, Brussels. Available online at: http://eur-lex.europa.eu/ legal-content/EN/TXT/?uri=CELEX:52011DC0031 (accessed on 7 November 2014).

European Commission (2012) Public Opinion in the European Union: First Results, Standard Eurobarometer 77, European Commission, Brussels. Available online at: http://ec.europa.eu/ public_opinion/archives/eb/eb77/eb77_first_en.pdf (accessed on 6 September 2012).

European Commission (2013a) The common agricultural policy (CAP) and agriculture in Europe - frequently asked questions, press release MEMO/13/631 released on 28 June. Available online at: http://europa.eu/rapid/press-release_MEMO-13-631_en.htm (accessed on 22 July 2013).

European Commission (2013b) Long term infrastructure vision for Europe and beyond. Available online at: http://eur-lex.europa.eu/legal-content/EN/ALL/?uri=CELEX:52013DC0711 (accessed on 29 August 2014).

European Commission (2014) on the exploration and production of hydrocarbons (such as shale gas) using high volume hydraulic fracturing in the EU. Available online at: http://eurlex.europa.eu/legal-content/EN/TXT/?uri=CELEX:52014DC0023R\%2801\%29 (accessed on 8 May 2014).

European Commission and EIB (2013) Increasing Lending to the Economy: Implementing the Eib Capital Increase and Joint Commission-Eib Initiatives, Joint Commission-EIB report to the European Council, 27-28 June. Available online at: http://ec.europa.eu/europe2020/pdf/ eib_en.pdf (accessed on 18 July 2013).

European Union (2012) The European Union explained: Energy, European Union, Luxembourg. Available online at: http://europa.eu/pol/index_en.htm (accessed on 27 July 2013).

Eurostat (2012a) Unemployment Rate, Monthly Average, European Commission. Available online at: http://appsso.eurostat.ec.europa.eu/nui/show.do?dataset=une_rt_m\&lang=en (accessed on 25 August 2012).

Eurostat (2012b) GDP and Main Components: Current prices, European Commission. Available online at: http://nui.epp.eurostat.ec.europa.eu/nui/show.do?dataset=namq_gdp_c\&lang=en (accessed on 28 August 2012).

Eurostat (2014a) Electricity prices components for domestic consumers, from 2007 onwards: annual data [nrg_pc_204_c]. Available online at: http://appsso.eurostat.ec.europa.eu/nui/ show.do?dataset=nrg_p $\mathrm{p}$ 204_c\&lang=en (accessed on 23 September 2014).

Eurostat (2014b) Statistical atlas: Eurostat regional yearbook 2014. Available online at: http://ec.europa.eu/eurostat/statistical-atlas/gis/viewer/ (accessed on October 16 2014).

FDIC (2009) Supervisory insights, Vol. 6, No. 1, Federal Deposit Insurance Corporation. Available online at: www.fdic.gov/regulations/examinations/supervisory/insights/sisum09/si_sum09.pdf (accessed on 5 September 2012).

Fernández-Reche, J., Cañadas, I., Sánchez, M., Ballestrín, J., Yebra, L., Monterreal, R., Rodríguez, J., García, G., Alonso, M. and Chenlo, F. (2006) 'PSA solar furnace: a facility for testing PV cells under concentrated solar radiation', Solar Energy Materials \& Solar Cells, Vol. 90, No. $15, \mathrm{pp} .2480-2488$.

Gnansounou, E. (2011) 'Measuring energy security vulnerability', in Sovacool, B.K. (ed.): The Routledge handbook of Energy Security, Routledge, Oxford, pp.396-413.

Griffith-Jones, S. and Jolly, R. (2013) 'Be outraged by austerity', Challenge, Vol. 56, No. 1, pp.40-60. 
Grossmann, W., Steininger, K.W., Schmid, C. and Grossmann, I. (2012) 'Investment and employment from large-scale photovoltaics up to 2050', Empirica, vol. 39, pp.165-189.

Hashmi, G., Miettunen, K., Peltola, T., Halme, J., Asgha, I., Aitola, K., Toivola, M. and Lund, P. (2011) 'Review of materials and manufacturing options for large area flexible dye solar cells', Renewable \& Sustainable Energy Reviews, vol. 15, No. 8, pp.3717-3732.

IMF (2012) 'Lagarde calls for urgent action so 2012 can be "year of healing", IMF Survey Magazine. Available online at: www.imf.org/external/pubs/ft/survey/so/2012/NEW0123 12A.htm (accessed on 6 September 2012).

Issing, O. (2000) Europe: Political Union though Common Money? Institute of Economic Affairs, Occasional paper 98.

Kennet, M., Drosos, D. and Tsotsolas, N. (2013) 'Editorial', International Journal of Green Economics, Vol. 7, No. 4, pp.315-319.

Keynes, J.M. (1936) The General Theory of Employment Interest and Money, MacMillan, London.

Kitromilides, Y. (2011) 'Deficit reduction, the age of austerity, and the paradox of insolvency', Journal of Post Keynesian Economics, Vol. 33, No. 3, pp.517-535.

Koo, R.C. (2013) 'Balance sheet recession as the "other half" of macroeconomics', European Journal of Economics and Economic Policies: Intervention, Vol. 10, No. 2, pp.136-157.

Minsky, H.P. (1992) The Financial Instability Hypothesis, Working Paper \#74, The Jerome Levy Economics Institute of Bard College.

Murchie, E.H., Pinto, M. and Horton, P. (2009) 'Agriculture and the new challenges for photosynthesis research', New Phytologist, Vol. 181, No. 3, pp.532-552.

Nielsen, T.D., Cruickshank, C., Foged, S., Thorsen, J. and Krebs, F.C. (2010) 'Business, market and intellectual property analysis of polymer solar cells', Solar Energy Materials \& Solar Cells, 94, No.10, pp.1553-1571.

Obama, B.H. (2012) Historical tables: budget of the United States Government, fiscal year 2013. Available online at: www.gpo.gov/fdsys/pkg/BUDGET-2013-TAB/xls/BUDGET-2013-TAB15-6.xls (accessed on 11 September 2012).

Observ'ER (2011) The state of renewable energies in Europe: 11th EurObserv'ER report. Available online at: http://observer.cartajour-online.com/Interface_Fondem/css/picture_libs/ barobilan11.pdf (accessed on 5 September 2012).

Observ'ER (2012) 'Photovoltaic barometer', EurObserv'ER, Vol. 7. Available online at: www.eurobserv-er.org/pdf/photovoltaic_2012.pdf (accessed on 4 September 2012).

OECD (2012) Industrial production index. Available online at: http://stats.oecd.org/Index.aspx? DataSetCode=REFSERIES (accessed on 25 July 2012).

OECD (2014a) Quarterly national accounts. Available online at: http://stats.oecd.org/\# (accessed on 2 September 2014).

OECD (2014b) Non-consolidated financial balance sheets by economic sector (quarterly table 0720). Available online at: http://stats.oecd.org/\# (accessed on 22 March 2014).

Pew Charitable Trusts (2012) Who's winning the clean energy race? 2011 edition. Available online at: www.pewtrusts.org//uploadedFiles/wwwpewtrustsorg/Reports/Clean_Energy/Clean\%20 Energy\%20Race\%20Report\%202012.pdf (accessed on 9 September 2012).

Prucnal, S., Abendroth, B., Krockert, K., König, K., Henke, D., Kolitsch, A., Möller, H.J. and Skorupa, W. (2012) 'Millisecond annealing for advanced doping of dirty-silicon solar cells', Journal of Applied Physics, Vol. 111, No. 12, pp.123104-123104-5.

Schäfer, H-B. (2012) 'The sovereign debt crisis in Europe: save banks not states', European Journal of Comparative Economics, Vol. 9, No. 2, pp.179-195.

Simmons, R.A., Coyle, E.D. and Chapman, B. (2014) 'Global energy policy perspectives', in Coyle, E.D. and Simmons, R.A. (eds): Understanding the Global Energy Crisis, Global Policy Research Institute/Purdue University Press, Lafayette, pp.27-72.

SolarGIS (2014) Global horizontal irradiation (GHI) map. Available online at: http://solargis. info/doc/free-solar-radiation-maps-GHI (accessed on 12 September 2014). 
Strobel, F. (2005) 'Leaving EMU: a real options perspective', Applied Economics, Vol. 37, pp.1449-1453.

Strobel, M.B., Betts, T.R., Friesen, G., Beyer, H.G. and Gottschalg, R. (2009) 'Uncertainty in photovoltaic performance parameters: dependence on location and material', Solar Energy Materials \& Solar Cells, 93, Nos. 6-7, pp.1124-1128.

Syrrakos, D. (2010) 'A reassessment of the Werner plan and the Delors report. Why did they experience a different fate?' Comparative Economic Studies, Vol. 52, pp.575-588.

Todorova, Z. (2013) 'Connecting social provisioning and functional finance in a post-Keynesian: institutional analysis of the public sector', European Journal of Economics and Economic Policies: Intervention, Vol. 10, No. 1, pp.61-75.

Worth, K.D. (2010) Peak Oil and the Second Great Depression (2010-2030): A Survival Guide for investors and savers after Peak Oil, Outskirts Press, Arvada, CO. 